\title{
Increased burden of rare deleterious variants of the KCNQ1 gene in patients with large-vessel ischemic stroke
}

\author{
PIOTR K. JANICKI ${ }^{1,2}$, CEREN EYILETEN ${ }^{3}$, VICTOR RUIZ-VELASCO ${ }^{2}$, JUSTYNA PORDZIK ${ }^{3}$, \\ ANNA CZLONKOWSKA ${ }^{3,4}$, IWONA KURKOWSKA-JASTRZEBSKA ${ }^{4}$, SHIGEKAZU SUGINO $^{1,2}$, \\ YUKA IMAMURA KAWASAWA ${ }^{5}$, DAGMARA MIROWSKA-GUZEL ${ }^{3}$ and MAREK POSTULA ${ }^{1,3}$ \\ ${ }^{1}$ Perioperative Genomics Laboratory; ${ }^{2}$ Department of Anesthesiology and Perioperative Medicine, \\ Penn State College of Medicine, Hershey, PA 17033, USA; ${ }^{3}$ Department of Experimental and Clinical Pharmacology, \\ Medical University of Warsaw, Center for Preclinical Research and Technology CEPT, Warsaw 02-097; \\ ${ }^{4}$ 2nd Department of Neurology, Institute of Psychiatry and Neurology, Warsaw 02-957, Poland; \\ ${ }^{5}$ Genome Sciences Facility, Penn State College of Medicine, Hershey, PA 17033, USA
}

Received October 15, 2018; Accepted January 30, 2019

DOI: $10.3892 / \mathrm{mmr} .2019 .9987$

\begin{abstract}
The impact of rare and damaging variants in genes associated with platelet function in large-vessel ischemic stroke (LVIS) remains unknown. The aim of this study was to investigate the contribution of some of these variants to the genetic susceptibility to LVIS in Polish patients using a deep re-sequencing of 54 selected genes, coding for proteins associated with altered platelet function. Targeted pooled re-sequencing (Illumina HiSeq 2500) was performed on genomic DNA of 500 cases (patients with history of clinically proven diagnosis of LVIS) and 500 age-, smoking status-, and sex-matched controls (no history of any type of stroke), and from the same population as patients with LVIS. After quality control and prioritization based on allele frequency and damaging probability, individual genotyping of all
\end{abstract}

Correspondence to: Professor Marek Postula, Department of Experimental and Clinical Pharmacology, Medical University of Warsaw, Center for Preclinical Research and Technology CEPT, 1B Banacha Street, Warsaw 02-097, Poland

E-mail: mpostula@wum.edu.pl

Abbreviations: LVIS, large-vessel ischemic stroke; CHO-M1, human muscarinic type 1 receptor; FLIPR, fluorescence imaging plate reader; GWAS, genome wide association studies; SNP, single nucleotide polymorphism; CAD, coronary artery disease; cMAF, cumulative minor allele frequency; CMAT, combined minor allele test; SNVs, single nucleotide variants; Fmin, minimum fluorescence; Fmax, maximum fluorescence; CADD, Combined Annotation Dependent Depletion; CHF, congestive heart failure; DM, diabetes mellitus; GIRK, G-protein-gated inwardly rectifying $\mathrm{K}^{+}$channels

Key words: DNA next-generation sequencing, platelets, genetic polymorphism, potassium channel, potassium voltage-gated channel subfamily Q member 1, large-vessel ischemic stroke, Polish population, FLIPR deleterious rare variants was performed in patients from the original cohort, and stratified to concomitant cardiac conditions differing between the study and stroke groups. We demonstrated a statistically significant increase in the number of rare and potentially damaging variants in some of the investigated genes in the LVIS pool (an increase in the genomic variants burden). Furthermore, we identified an association between LVIS and 6 rare functional and damaging variants in the Kv7.1 potassium channel gene (KCNQ1). The predicted functional properties (partial loss-of function) for the three most damaging variants in $K C N Q 1$ coding locus were further confirmed in vitro by analyzing the membrane potential changes in cell lines co-transfected heterogeneously with human muscarinic type 1 receptor and wild-type or mutated KCNQ1 cDNA constructs using fluorescence imaging plate reader. The study demonstrated an increased rare variants burden for 54 genes associated with platelet function, and identified a putative role for rare damaging variants in the $K C N Q 1$ gene on LVIS susceptibility in the Polish population.

\section{Introduction}

Previous genomic studies identified several common genetic variants that could play a role in large-vessel ischemic stroke (LVIS) (1). Precise type of their effect on brain ischemia remains unclear, and it is assumed that common genetic variants could explain between $39-66 \%$ of variation in ischemic stroke incidence (2). It has also been postulated that the accumulated effect of the remaining uncommon or rare damaging variants (called genetic burden) might explain a significant portion of the genetic predisposition to many common diseases or phenotypes $(3,4)$. A small number of re-sequencing reports of European patients with LVIS were published so far. These studies have demonstrated that infrequent coding variants in numerous genes might be linked to stroke (5-8).

Platelets have an important role in the pathogenesis of LVIS based on their activation and adherence to the 
endothelium within cerebral arteries, as well as progression of thrombus $(9,10)$. Most research strategies to date revealed the effect of genetic variation on reactivity of platelets and were obtained by analyzing common variants within candidate genes and/or genome-wide association studies (GWAS), followed by in vitro studies to assess platelet functions (11). Overall, previous studies on the genetic background of platelet reactivity indicated that many different genes contribute to platelet function. Thus far, the potential contribution of genetic variants within genes encoding proteins essential to thrombus formation in LVIS have been analyzed in a small number of studies and the majority of them focused on the common single nucleotide polymorphisms (SNPs) within a few genes associated with glycoproteins on the platelet surface (11). The results of these studies suggested that additional loci associated with platelet functions are yet to be found and that the known loci may contain high effect rare risk variants that have thus far gone undetected by GWAS.

Rare coding variants appear to be restricted to small populations and that was shown in only one previous study, which concentrated on the re-sequencing of the common variants in the platelet genes associated with membrane function (12). In addition, another recent investigation revealed that the rare variants in receptors commonly associated with platelet functions (e.g. purinergic receptors) could be associated with the occurrence of LVIS in the Polish population (13).

Thus, the objective of our current study was to explain the contribution played by the another set of uncommon and damaging genetic variants within selected genes associated with changes in platelet functions in LVIS. We have chosen 54 genes associated with less known or investigated biochemical processes associated with platelet functions as the focus for the re-sequencing study (14-21).

\section{Materials and methods}

Clinical material. The study was permitted by both local ethics committee of the Institute of Psychiatry and Neurology, Warsaw, Poland, and Warsaw Medical University, Warsaw, Poland. The study conduct conformed to the most recent version of the Declaration of Helsinki. All participants in the study signed the informed consent. Full description of the study cohort, including the inclusion and exclusion criteria were published previously $(12,13,22-24)$. Based on the Trial of Org 10172 in Acute Stroke Treatment (TOAST) classification we included: i) All patients classified as having ischemic stroke due to large-vessel atherosclerosis and ii) a subset of patients classified as having ischemic stroke of unknown etiology, provided they had at least $50 \%$ stenosis of the carotid artery ipsilateral to the infarct side and no evidence or no history of atrial fibrillation. Patient with the history of hemorrhagic or embolic stroke were excluded from the study. As a control group we used samples from age- and sex-matched 500 patients without history of stroke coming from the same geographical area as patients with LVIS (13) and collected for unrelated studies performed at Warsaw Medical University in Poland. Both cohorts of patients (study and control) were white Caucasian of Polish ethnicity and originated from central Poland. DNA extraction from collected blood samples was done as described before (9).
Pooled sequencing. The list of 54 re-sequenced genes is shown in Table I. These targets contain 846 exons and 10 adjoining bases beyond each exon on both sides. The genetic loci were selected using the human database (H. sapiens, hg19, GRCh37, February 2009). Pooled targeted enrichment of DNA, from LVIS patients (five polls with 100 subjects per pool) and 500 age-, sex-matched control patients, without stroke history (five pools with 100 subjects per pool), was done as described previously. Further explanation of re-sequencing and analysis of data is provided in the Supplementary material (Tables SI-SIV).

Verification of selected variants by individual genotyping. Individual genotyping for selected markers in individual DNA samples was performed using a custom Sequenom iPLEX assay in conjunction with the Mass ARRAY platform (Sequenom Inc., La Jolla, CA, USA). Panels of SNP markers were designed using Sequenom Assay Design 3.2 software (Sequenom Inc.), in a similar fashion to the previously described methodology from our laboratory $(9,16,17)$.

Statistical analysis. A cumulative minor allele frequency (cMAF) was utilized to show the allelic frequency of the investigated variants, which encompasses all rare damaging variants individually genotyped in the investigated cohorts, as well as within each of the analyzed loci. Pearson Chi-square test was used in order to analyze differences in cMAF for all individually genotyped variants between the study and control cohorts (VassarStats: Website for Statistical Computation on http://vassarstats.net/). The pooled minor allele test (CMAT) (10,000 x permutations) was used for comparison of all variants within investigated loci to estimate the statistical significance of the observed differences in the accumulation of variants. CMAT is a pooling method proposed by Zawistowski et al (25) and works by comparing weighted minor-allele counts (for cases and controls) against the weighted major-allele counts (for cases and controls). Although the CMAT test statistic is based on a chi-square statistic, it does not follow a known distribution and its significance has to be determined by a permutation procedure. The calculations of CMAT were performed using AssotesR package (0.1-10) from CRAN repository (cran.r-project. org/package $=$ AssotesteR) and written by Gaston Sanchez (gastonsanchez.com/) as documented at www.rdocumentation. org/packages/AssotesteR/versions/0.1-10. The significance threshold was adjusted to the number of re-sequenced loci, when needed $(13,25)$.

Power and sample size considerations. For the power calculations, instead of using individual rare variants, we decided to use predicted cMAF for all deleterious rare variants in the sequenced loci. We have followed a self-sufficient, closed-form, maximum-likelihood estimator for allele frequencies that accounts for errors associated with sequencing, and a likelihood-ratio test statistic that provides a simple means for evaluating the null hypothesis of monomorphism $(13,26,27)$. Unbiased estimates of allele frequencies $10 / \mathrm{N}$ (where $\mathrm{N}$ is the number of individuals sampled) appear to be achievable, and near-certain identification of a single nucleotide polymorphism (SNP) requires a cMAF of at least 0.01 (i.e., 10 variants 
Table I. List of 54 platelet genes with exons sequenced in the present study.

\begin{tabular}{|c|c|c|c|c|}
\hline Author, year & Gene & Protein encoded & $\begin{array}{l}\text { Chromosome and } \\
\text { regions }\end{array}$ & (Ref.) \\
\hline Janicki et al, 2017 & FCERIG & $\begin{array}{l}\text { Fc fragment of IgE, high affinity I, receptor for; } \\
\gamma \text { polypeptide }\end{array}$ & 1q23.3region & (13) \\
\hline Janicki et al, 2017 & $V A V 3$ & vav 3 guanine nucleotide exchange factor & $1 \mathrm{p} 13.3$ & (13) \\
\hline Jones et al, 2009 & $R A F 1$ & v-raf-1 murine leukemia viral oncogene homolog 1 & $3 \mathrm{p} 25.1$ & (14) \\
\hline Jones et al, 2009 & MAPK14 & Mitogen-activated protein kinase 14 & $6 \mathrm{p} 21.31$ & (14) \\
\hline Jones et al, 2009 & $J A K 2$ & Janus kinase 2 & $9 \mathrm{p} 24.1$ & (14) \\
\hline Jones et al, 2009 & $M A P 2 K 4$ & Mitogen-activated protein kinase kinase 4 17. p12 & $17 \mathrm{p} 12$ & (14) \\
\hline Jones et al, 2009 & $A K T 2$ & v-akt murine thymoma viral oncogene homolog 2 & $19 q 13.1-q 13.2$ & (14) \\
\hline Jones et al, 2009 & $M A P 2 K 2$ & Mitogen-activated protein kinase kinase 2 & $19 \mathrm{p} 13.3$ & (14) \\
\hline Jones et al, 2009 & GNAZ & $\begin{array}{l}\text { Guanine nucleotide binding protein ( } G \text { protein }) \text {, } \\
\alpha \text { z polypeptide }\end{array}$ & $22 q 11.22$ & (14) \\
\hline $\begin{array}{l}\text { Jones et al, 2009; } \\
\text { Goodall et al, } 2010\end{array}$ & TRIM27 & Tripartite motif containing 27 & $6 \mathrm{p} 22.1$ & $(14,15)$ \\
\hline Goodall et al, 2010 & LRRFIP1 & Leucine rich repeat (in FLII) interacting protein 1 & $2 q 37.3$ & $(15)$ \\
\hline Goodall et al, 2010 & COMMD7 & COMM domain containing 7 & $20 q 11.21$ & $(15)$ \\
\hline Postula et al, 2013 & $R G S 7$ & Regulator of G-protein signaling 7 & 1q23.1 & $(16)$ \\
\hline Guerrero et al, 2011 & LPAR1 & Lysophosphatidic acid receptor 1 & $9 q 31.3$ & $(17)$ \\
\hline Guerrero et al, 2011 & MYO5B & Myosin VB & $18 \mathrm{q} 21.1$ & (17) \\
\hline Mathias et al, 2010 & LDHAL6A & Lactate dehydrogenase A-like 6A & $11 \mathrm{p} 15.1$ & (18) \\
\hline Mathias et al, 2010 & $A N K S 1 B$ & $\begin{array}{l}\text { Ankyrin repeat and sterile } \alpha \text { motif domain } \\
\text { containing } 1 \mathrm{~B}\end{array}$ & $12 \mathrm{q} 23.1$ & (18) \\
\hline Johnson et al, 2010 & $P I K 3 C G$ & $\begin{array}{l}\text { Phosphoinositide-3-kinase, catalytic, } \gamma \\
\text { polypeptide }\end{array}$ & $7 q 22.3$ & (19) \\
\hline Johnson et al, 2010 & $\mathrm{SHH}$ & Sonic hedgehog homolog & $7 q 36.3$ & (19) \\
\hline Johnson et al, 2010 & $J M J D 1 C$ & Jumonji domain containing $1 \mathrm{C}$ & $10 q 21.2$ & (19) \\
\hline Johnson et al, 2010 & MRVII & Murine retrovirus integration site 1 homolog & $11 \mathrm{p} 15.4$ & (19) \\
\hline $\begin{array}{l}\text { Johnson et al, 2010; } \\
\text { Johnson, } 2011\end{array}$ & $R G S 18$ & Regulator of G-protein signaling 18 & $1 \mathrm{q} 31.2$ & $(19,20)$ \\
\hline $\begin{array}{l}\text { Johnson et al, 2010; } \\
\text { Johnson, } 2011\end{array}$ & ST3GAL3 & ST3 $\beta$-galactoside $\alpha$-2,3-sialyltransferase 3 & $1 \mathrm{p} 34.1$ & $(19,20)$ \\
\hline $\begin{array}{l}\text { Johnson et al, 2010; } \\
\text { Johnson, } 2011\end{array}$ & UGT1A10 & $\begin{array}{l}\text { UDP glucuronosyltransferase } 1 \text { family, } \\
\text { polypeptide A10 }\end{array}$ & $2 q 37.1$ & $(19,20)$ \\
\hline $\begin{array}{l}\text { Johnson et al, 2010; } \\
\text { Johnson, } 2011\end{array}$ & NUP210 & Nucleoporin $210 \mathrm{kDa}$ & $3 \mathrm{p} 25.1$ & $(19,20)$ \\
\hline $\begin{array}{l}\text { Johnson et al, 2010; } \\
\text { Johnson, } 2011\end{array}$ & RAPGEF2 & Rap guanine nucleotide exchange factor (GEF) 2 & $4 q 32.1$ & $(19,20)$ \\
\hline $\begin{array}{l}\text { Johnson et al, 2010; } \\
\text { Johnson, } 2011\end{array}$ & ADAMTS2 & $\begin{array}{l}\text { ADAM metallopeptidase with thrombospondin } \\
\text { type } 1 \text { motif, } 2\end{array}$ & $5 q 35.3$ & $(19,20)$ \\
\hline $\begin{array}{l}\text { Johnson et al, 2010; } \\
\text { Johnson, } 2011\end{array}$ & $F B X L 7$ & F-box and leucine-rich repeat protein 7 & $5 \mathrm{p} 15.1$ & $(19,20)$ \\
\hline $\begin{array}{l}\text { Johnson et al, 2010; } \\
\text { Johnson, } 2011\end{array}$ & KLHL31 & Kelch-like family member 31 & $6 \mathrm{p} 12.1$ & $(19,20)$ \\
\hline $\begin{array}{l}\text { Johnson et al, 2010; } \\
\text { Johnson, } 2011\end{array}$ & $G M D S$ & GDP-mannose 4,6-dehydtase & $6 \mathrm{p} 25.3$ & $(19,20)$ \\
\hline $\begin{array}{l}\text { Johnson et al, 2010; } \\
\text { Johnson } 2011\end{array}$ & WBSCR 17 & Williams-Beuren syndrome chromosome region 17 & $7 q 11.22$ & $(19,20)$ \\
\hline
\end{tabular}


Table I. Continued.

\begin{tabular}{|c|c|c|c|c|}
\hline Author, year & Gene & Protein encoded & $\begin{array}{l}\text { Chromosome and } \\
\text { regions }\end{array}$ & (Ref.) \\
\hline $\begin{array}{l}\text { Johnson et al, 2010; } \\
\text { Johnson, } 2011\end{array}$ & ATP6V1F & $\begin{array}{l}\text { ATPase, } \mathrm{H}^{+} \text {transporting, lysosomal } 14 \mathrm{kDa} \text {, } \\
\text { V1 subunit } \mathrm{F}\end{array}$ & $7 q 32.1$ & $(19,20)$ \\
\hline $\begin{array}{l}\text { Johnson et al, 2010; } \\
\text { Johnson, } 2011\end{array}$ & $S G C Z$ & Sarcoglycan, $\zeta$ & $8 \mathrm{p} 22$ & $(19,20)$ \\
\hline $\begin{array}{l}\text { Johnson et al, 2010; } \\
\text { Johnson, } 2011\end{array}$ & STMN4 & Stathmin-like 4 & $8 \mathrm{p} 21.2$ & $(19,20)$ \\
\hline $\begin{array}{l}\text { Johnson et al, 2010; } \\
\text { Johnson, } 2011\end{array}$ & PSKH2 & Protein serine kinase $\mathrm{H} 2$ & $8 \mathrm{q} 21.3$ & $(19,20)$ \\
\hline $\begin{array}{l}\text { Johnson et al, 2010; } \\
\text { Johnson, } 2011\end{array}$ & $P I P 5 K 1 B$ & $\begin{array}{l}\text { Phosphatidylinositol-4-phosphate 5-kinase, } \\
\text { type I, } \beta\end{array}$ & $9 \mathrm{q} 21.11$ & $(19,20)$ \\
\hline $\begin{array}{l}\text { Johnson et al, 2010; } \\
\text { Johnson, } 2011\end{array}$ & $P T P R D$ & Protein tyrosine phosphatase, receptor type, D & $9 \mathrm{p} 24.1$ & $(19,20)$ \\
\hline $\begin{array}{l}\text { Johnson et al, 2010; } \\
\text { Johnson, } 2011\end{array}$ & MIPOLl & Mirror-image polydactyly 1 & $14 \mathrm{q} 13.3-\mathrm{q} 21.1$ & $(19,20)$ \\
\hline $\begin{array}{l}\text { Johnson et al, 2010; } \\
\text { Johnson, } 2011\end{array}$ & $S V I L$ & Supervillin & $10 p 11.23$ & $(19,20)$ \\
\hline $\begin{array}{l}\text { Johnson et al, 2010; } \\
\text { Johnson, } 2011\end{array}$ & $C U B N$ & Cubilin (intrinsic factor-cobalamin receptor) & $10 \mathrm{p} 13$ & $(19,20)$ \\
\hline $\begin{array}{l}\text { Johnson et al, 2010; } \\
\text { Johnson, } 2011\end{array}$ & ST3GAL4 & ST3 $\beta$-galactoside $\alpha$-2,3-sialyltransferase 4 & $11 \mathrm{q} 24.2$ & $(19,20)$ \\
\hline $\begin{array}{l}\text { Johnson, } 2010 \\
\text { Johnson, } 2011\end{array}$ & $K C N Q 1$ & $\begin{array}{l}\text { Potassium voltage-gated channel, KQT-like } \\
\text { subfamily, member } 1\end{array}$ & $11 \mathrm{p} 15.5-\mathrm{p} 15.4$ & $(19,20)$ \\
\hline $\begin{array}{l}\text { Johnson et al, 2010; } \\
\text { Johnson, } 2011\end{array}$ & HSD17B6 & Hydroxysteroid (17- $\beta$ ) dehydrogenase 6 & $12 q 13.3$ & $(19,20)$ \\
\hline $\begin{array}{l}\text { Johnson et al, 2010; } \\
\text { Johnson, } 2011\end{array}$ & $R A P I B$ & RAP1B, member of RAS oncogene family & $12 q 15$ & $(19,20)$ \\
\hline $\begin{array}{l}\text { Johnson et al, 2010; } \\
\text { Johnson, } 2011\end{array}$ & PTPN11 & Protein tyrosine phosphatase, non-receptor type 11 & $12 q 24$ & $(19,20)$ \\
\hline $\begin{array}{l}\text { Johnson et al, 2010; } \\
\text { Johnson, } 2011\end{array}$ & THSD4 & Thrombospondin, type I, domain containing 4 & $15 q 23$ & $(19,20)$ \\
\hline $\begin{array}{l}\text { Johnson et al, 2010; } \\
\text { Johnson, } 2011\end{array}$ & TAOK1 & TAO kinase 1 & $17 \mathrm{q} 11.2$ & $(19,20)$ \\
\hline $\begin{array}{l}\text { Johnson et al, 2010; } \\
\text { Johnson, } 2011\end{array}$ & SETBPI & SET binding protein 1 & $18 \mathrm{q} 12.3$ & $(19,20)$ \\
\hline $\begin{array}{l}\text { Johnson et al, 2010; } \\
\text { Johnson, } 2011\end{array}$ & KIAA0802 & SOGA family member 2 & $18 \mathrm{p} 11.22$ & $(19,20)$ \\
\hline $\begin{array}{l}\text { Johnson et al, 2010; } \\
\text { Johnson, } 2011\end{array}$ & CTCFL & CCCTC-binding factor (zinc finger protein)-like & $20 \mathrm{q} 13.31$ & $(19,20)$ \\
\hline $\begin{array}{l}\text { Johnson et al, 2010; } \\
\text { Johnson, } 2011\end{array}$ & $P C K 1$ & Phosphoenolpyruvate carboxykinase 1 & $20 q 13.31$ & $(19,20)$ \\
\hline $\begin{array}{l}\text { Johnson et al, 2010; } \\
\text { Johnson, } 2011\end{array}$ & $P R N P$ & Prion protein & $20 \mathrm{p} 13$ & $(19,20)$ \\
\hline Shiffman et al, 2006 & VAMP8 & Vesicle-associated membrane protein 8 & 2p12-p11.2 & (21) \\
\hline Lee et al, 2014 & GLIS3 & GLIS family zinc finger 3 & $9 \mathrm{p} 24.2$ & (26) \\
\hline
\end{tabular}


per cohort). In addition, because the power to detect significant allele-frequency differences between the two populations is limited, we set both the number of sampled individuals (500 in the cohort) and depth of sequencing coverage in excess of 100.

Fluorescence-based (FLIPR) functional assay for KCNQ1 variants. Chinese hamster ovaries cells $(\mathrm{CHO})$ cultures stably transfected with human muscarinic type 1 receptor (M1) were purchased from cDNA Resource Center, Bloomberg, PA. The CHO-M1 cells were then transiently co-transfected with KCNQ1 cDNA constructs. Wild-type KCNQ1 cDNA constructs (in pcDNA3.1) were prepared by Watson Bio Sciences (Houston, TX, USA). The fidelity of the mutations for each variant was confirmed by Sanger sequencing. Details about the transfection techniques and cell culture conditions used in our laboratory were published before (13).

The heterologous expressed potassium KCNQ1 channels were inhibited by the M1 receptor agonist oxotremorine (OxoM, $10 \mathrm{nM}$ ), resulting in significant changes in membrane polarization (fully antagonized by muscarinic receptor antagonist atropine at $1 \mu \mathrm{M}$-not shown).

The Fluorescence Imaging Plate Reader (FLIPR) on Flex Station 3 (Molecular Devices, San Jose, CA, USA) was employed to measure the fluorescence changes. After the cells were loaded with membrane dye, the plate with the cells and plate containing OxoM (10 nM) were inserted into the plate reader. The raw fluorescence readings were converted and plotted as the change in relative fluorescence before (F0 baseline $=100 \%$ ) and after OxoM application $\mathrm{F}$ ), according to the formula $\left((\mathrm{F} / \mathrm{F} 0)^{*} 100 \%\right)$. For all experimental conditions, minimum fluorescence (Fmin) and maximum fluorescence (Fmax) were recorded in triplicates after administration. The summary data are presented as summary trend lines for WT and mutants, as well as averages (with standard deviations) for Fmax and Fmin and for each variant and WT cells used in FLIPR experiments. The final data represent all measurements done in triplicates and in three independent experiments (cell populations). Data and statistical analysis were performed using analysis of variance, followed by the Student's t-test. $\mathrm{P}<0.05$ was considered to indicate a statistically significant difference.

\section{Results}

Study design and sequencing coverage. The design of the study is presented in Fig. 1. The enrichment of the target loci resulted in coverage of $99.6 \%$ and produced 36.1 (22.7-45.9 range) million reads which is 5.3 (3-7 range) Gbp per re-sequenced sample. It relates to an average coverage of 12,000x per pool and an average coverage of 120x per patient sample (range 21-369).

Selection of rare variants (based on $M A F<1 \%$ ). The step-wise analysis of the observed variants is presented in Fig. 2. In total, 1018 unique variants, irrespective of MAF and with adequate quality were observed in both investigated cohorts. The complete list of all observed variants is provided in the Supplementary materials, Tables SII for all non-coding variants and SIII for all non-synonymous variants. Seventy two percent of all variants were previously listed in the available databases, and $28 \%$ were new. Out of all observed variants, 327 (32.1\%) were located in the coding segments of the sequenced genes, and the remainder was located in untranslated regions. Out of all coding variants, 120 variants (Supplementary material, Table SIV-list of all rare non-synonymous variants) were selected based on MAF < $1 \%$ (i.e. rare variants) (28), which consisted of 52 known (by dbSNP149 November 2016) and 68 unlisted, novel variants.

Verification of selected variants by individual genotyping. In total, $28 \mathrm{SNVs}$ with the highest predicted damaging score calculated by Combined Annotation Dependent Depletion (CADD) score were chosen for individual genotyping. The minimum CADD score of 10 served as a threshold for predicted deleteriousness. The individual genotyping was performed in patients from the original cohort and revealed that the identity of all 28 initially selected variants could be confirmed by individual genotyping, which indicates no sequencing errors for these variants.

The initial statistical analysis utilized Pearson's Chi-square test for the assessment of the differences in the cumulative frequency of all 28 individually genotyped variants between the investigated cohorts. There was a highly statistically significant $(\mathrm{P}=0.00045)$ difference (cMAF control $=1.2 \%$ vs. $\mathrm{cMAF}$ stroke $=3.6 \%$ ) in cMAF for all damaging variants in the LVIS group when compared with controls.

The statistical analysis of the number of variants within the single gene loci was based on combined minor allele association test (CMAT). The region-based, Bonferroni corrected, significance threshold was $\mathrm{P}=0.00092$ (nominal $\mathrm{P}=0.05 / 54$ sequenced genes). It demonstrated a statistically significant difference $(\mathrm{P}=0.0009)$ between control and IS cohorts for the $K C N Q 1$ location. The $K C N Q 1$ exons locus contained 3 novel and 3 known rare and deleterious (CADD score range 13.22-39) coding variants (Table II).

Functional analysis of selected rare variants within KNCQ1 gene. To evaluate whether the observed variants exert a damaging effect on $K C N Q 1$ function, we selected 3 novel and most damaging variants from the $K C N Q 1$ locus to examine the coupling between the heterologous expressed human M1 receptor and KCNQ1 channels in CHO-M1 cells (Table III). Fig. 3 shows the summary of changes in relative fluorescence for CHO-M1 cells expressing wild-type $K C N Q 1$, and variants $K C N Q 1$ c. G855T p. K285N, KCNQ1 c. G1545T p. K515N, and $K C N Q 1$ c. $1637 \mathrm{~A}$ p. S546X. Following oxoM application (final concentration $10 \mathrm{nM}$ ), the fluorescence decreased rapidly, indicating corresponding changes in cell membrane potential. We expressed the changes in fluorescence both as the differences between baseline fluorescence and its changes (in $\%$ of baseline $=\mathrm{Fo}=100 \%$ ) over $250 \mathrm{sec}$ after administration of oxoM (shown as trend line for all observations) and average values of minimum (Fmin) and maximum (Fmax) of relative fluorescence during the recording period (separately for WT and variants). The provided trend lines represent summary values for all observations (2-3 independent cell cultures and all measurements in triplicates of plate wells). A significant decrease in fluorescence signal for each variant was observed after administration of oxoM when compared with the KCNQ1 wild-type-expressing CHO-M1 cells. Correspondingly, the statistically significant decrease $(\mathrm{P}<0.05$ 

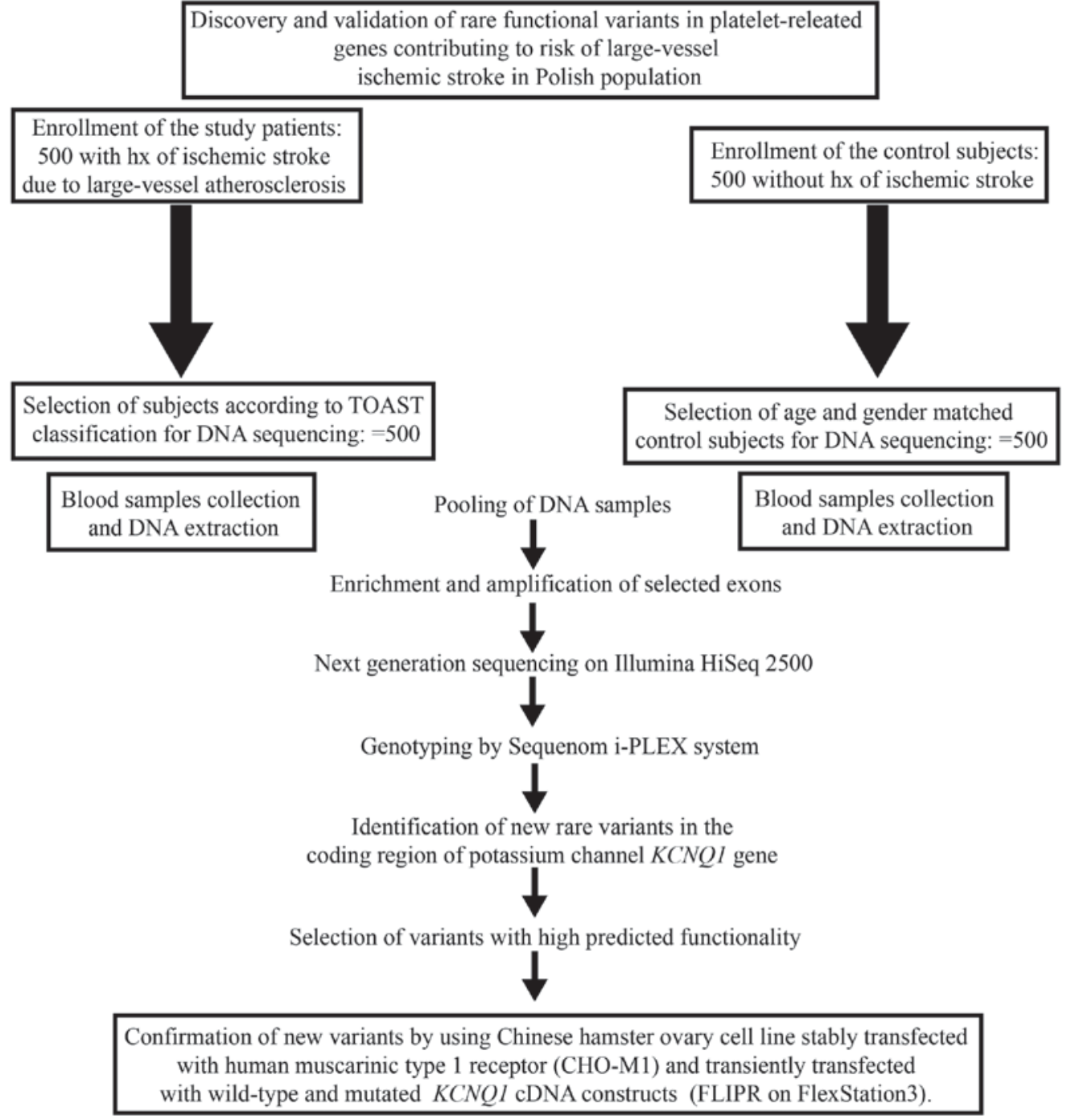

Figure 1. Study-flow diagram. TOAST, Trial of Org 10172 in Acute Stroke Treatment; hx, history; KCNQ1, potassium voltage-gated channel subfamily Q member 1; FLIPR, fluorescence imaging plate reader.

ANOVA, followed by t-test) in the average Fmin and Fmax was observed for all 3 investigated variants, indicating at least partial loss-of-function characteristics for variant proteins, when compared to WT.

\section{Discussion}

We present the results of the analysis of the genetic burden of the infrequent coding variants in 54 genes associated with platelet function and its possible association with LVIS. The assessment of MAF for the investigated uncommon coding variants established that there was a significant accumulation of those variants in the LVIS group when compared to the control group. By grouping these variants by sequenced loci instead of analyzing them individually, we were able to observe associations which could be underpowered when applied to single variants, as shown in previous studies of other traits $(12,13)$. In particular, we found an association between the increased accumulation of rare variants in $K C N Q 1$ locus and LVIS. It is important to note that, with the exception of 3 already known variants, the remaining 3 observed damaging variants within $K C N Q 1$ locus were novel. It is therefore likely that at least some of the observed variants might be restricted to the Polish cohort. So far detailed genotypes in the Polish population have been rather poorly characterized in the available genomic databases. This in turn might suggest that the verification of the obtained results in the independent cohorts could be challenging. For example, it was previously demonstrated that, at least in case of rare damaging variants associated with ulcerative colitis, the rare variants observed in the Dutch population could not be replicated in a German cohort (29). Another study on inflammatory bowel disease, that included several thousands of European individuals and individuals of other ancestry, showed that although the majority of the loci with MAF $>5 \%$ were shared between different ancestry groups (30), no such similarities were observed for uncommon alleles. In fact, rare variants were even more likely to be specific to a particular population, as was confirmed by a recent sequencing study (31). What is more, rare variants might differ significantly among even closely related populations (32).

We were able to observe only few (out of several hundreds) of previously listed rare coding variants in the KCNQ1 locus, which might indicate either limited power of the study or 
Table II. cMAF for 28 rare and most damaging variants observed in the individually genotyped patients from control and LVIS cohorts.

\begin{tabular}{|c|c|c|c|}
\hline Gene locus & $\begin{array}{l}\text { Number of carriers in } \\
\text { control cohort, } n=500\end{array}$ & $\begin{array}{l}\text { Number of carriers in } \\
\text { LVIS cohort, } n=500\end{array}$ & P-value \\
\hline$A D A M T 2$ & 2 & 3 & 0.4 \\
\hline$C U B N$ & 0 & 4 & 0.06 \\
\hline GLIS3 & 2 & 0 & 0.1 \\
\hline$K C N Q 1$ & 0 & 6 & $0.0009^{\mathrm{a}}$ \\
\hline LDHAL6A & 3 & 2 & 0.4 \\
\hline$M A P 2 K 2$ & 0 & 2 & 0.2 \\
\hline MIPOL1 & 0 & 2 & 0.8 \\
\hline MTCL1 & 4 & 3 & 0.9 \\
\hline МYO5B & 0 & 4 & 0.06 \\
\hline PTPRJ & 0 & 2 & 0.1 \\
\hline $\mathrm{SHH}$ & 0 & 2 & 0.1 \\
\hline SVIL & 1 & 3 & 0.15 \\
\hline UGT1A1 & 0 & 2 & 0.1 \\
\hline Total number of carriers and cMAF for all loci & 12 & 36 & $0.00045^{\mathrm{b}}$ \\
\hline Odds ratio and $95 \%$ confidence intervals (in brackets) & & $3.07(1.59-5.94)$ & \\
\hline
\end{tabular}

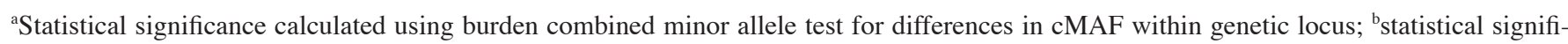
cance calculated using Pearson's $\chi^{2}$ test for differences in cMAF for all loci. cMAF, cumulative minor allele frequency; LVIS, large-vessel ischemic stroke.

Table III. Rare coding variants for $K C N Q 1$ gene observed in the study patients, as identified by exome sequencing and verified by individual genotyping.

\begin{tabular}{lllccllr}
\hline dbSNP & $\begin{array}{c}\text { MAFctrl } \\
\text { pooled }\end{array}$ & $\begin{array}{c}\text { MAFstroke } \\
\text { pooled }\end{array}$ & $\begin{array}{c}\text { MAF individual } \\
\text { genotyping in control }\end{array}$ & $\begin{array}{c}\text { MAF in individual } \\
\text { genotyping in stroke }\end{array}$ & $\begin{array}{c}\text { DNA } \\
\text { change }\end{array}$ & $\begin{array}{c}\text { Amino acid } \\
\text { change }\end{array}$ & CADD \\
\hline rs12720457 & $0.80 \%$ & ND & $0.01 \%$ & ND & c.G1179T & p.K393N & 6.560 \\
Novel & ND & $0.75 \%$ & ND & $0.1 \%$ & c.G4T & p.D2Y & 5.53 \\
rs199472712 & ND & $0.95 \%$ & ND & $0.1 \%$ & c.G724T & p.D242Y & 19.35 \\
Novel & ND & $\mathbf{0 . 7 4 \%}$ & ND & $\mathbf{0 . 1 \%}$ & c.G855T & p.K285N & $\mathbf{1 5 . 4 8}$ \\
Novel & ND & $\mathbf{0 . 6 5 \%}$ & ND & $\mathbf{0 . 1 \%}$ & c.G1545T & p.K515N & $\mathbf{1 3 . 2 2}$ \\
rs199472793 & ND & $0.71 \%$ & ND & $0.1 \%$ & c.C1597T & p.R533W & 15.28 \\
Novel & ND & $\mathbf{0 . 8 5 \%}$ & ND & $\mathbf{0 . 1 \%}$ & c.C1637A & p.S546X & $\mathbf{3 9}$ \\
\hline
\end{tabular}

Novel variants marked in bold were additionally investigated in the in vitro functional test. cMAF $=0.01 \%$ for MAF individual genotyping in control. $\mathrm{cMAF}=0.06 \% \mathrm{MAF}$ in individual genotyping in stroke, $\mathrm{P}=0.0009$ using combined minor allele test for comparison of coding rare variants in the KCNQ1 gene. cMAF, cumulative minor allele frequency; ND, not detected; CADD, Combined Annotation Dependent Depletion score; KCNQ1, potassium voltage-gated channel subfamily Q member 1.

population-specific distribution of these variants. Further studies in other populations will be helpful to verify if the rare damaging variants in the $K C N Q 1$ coding locus are indeed associated with large-vessel IS, or also with other types of stroke (small-vessel and embolic).

The KCNQ channels, members of the voltage-gated $\left(\mathrm{K}_{\mathrm{V} 7.1}\right)$ $\mathrm{K}^{+}$-selective channel subfamily, play a major role in $\mathrm{K}^{+}$ion transport. For instance, previous studies have shown that both $\mathrm{K}_{\mathrm{V}}$ channels KCNA3 and $\mathrm{G}$ protein-gated inwardly rectifying $\mathrm{K}^{+}$channels $(\mathrm{GIRK})$ regulate platelet activation $(33,34)$. The presence of Kv7.1 channel in blood cells, including platelets, suggests that they play a role in agonist-mediated regulation of platelet-driven thrombotic pathways that is crucial to hemostasis during IS $(35,36)$.

Our in vitro results indicate that oxoM-mediated changes in the membrane potential of cells expressing M1 receptors and KCNQ1 channel variants were attenuated (loss-of-function characteristics) when compared to cells expressing the wild-type receptors. These findings suggest that the signaling might be diminished in cells expressing the mutant KCNQ1 channels. The coding variants in $K C N Q 1$ were previously evaluated in different cardiovascular diseases and DM (37-41). It has been also 
$\underline{54 \text { sequenced genes with } 846 \text { exons }}$

All variants detected in pooled samples: 1018 (72\% known and $28 \%$ new

327 coding (protein changing) variants

120 rare $(\mathrm{MAF}<1 \%)$ coding variants $(52 \%$

known, $48 \%$ new)

89 rare coding variants with

predicted deleterious properties

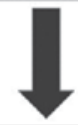

28 rare coding variants with highest

damaging score selected for individual genotyping

Figure 2. Number and characteristics of variants identified at each stage of the step-wise variant analysis. MAF, minor allele frequency.

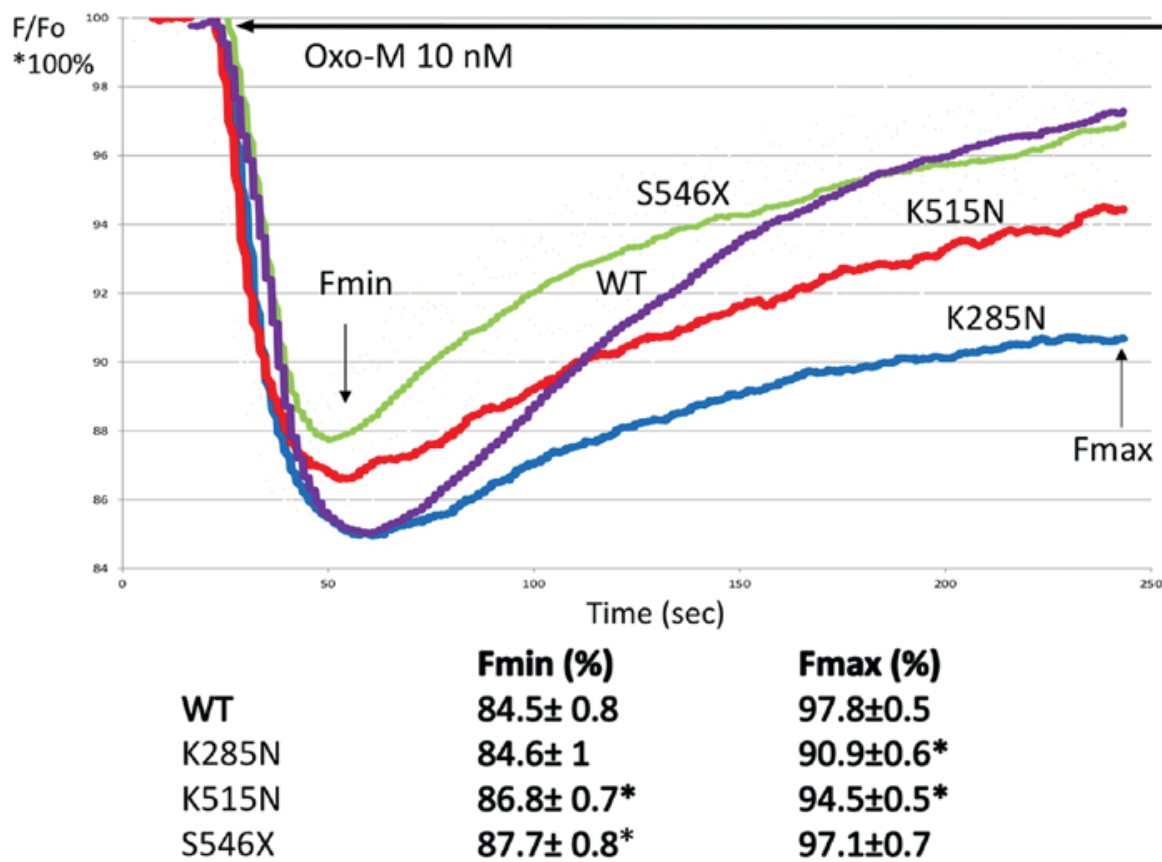

Figure 3. Effect of Oxo-M on relative fluorescence in CHO-M1 cells heterologously expressing KCNQ1 wild-type and KCNQ1 variant channels. Each panel shows \% change (from baseline $\mathrm{Fo}=100 \%$ ) of $\mathrm{F}$ in $\mathrm{CHO}-\mathrm{M} 1$ transfected with wild-type $\mathrm{K} 285 \mathrm{~N}, \mathrm{~K} 515 \mathrm{~N}$ and S546X variants (where $\mathrm{X}$ is random amino acid substituted). Fluorescence signals were acquired before and during Oxo-M (10 nM, solid line) application. The data are presented trend lines for all the experimental points (2-3 independent experiments, triplicate measurements). For each variant and the calculated Fmin and Fmax relative fluorescence change, including standard deviation was calculated. Fmax and Fmin averages were compared with WT using analysis of variance, followed by a t-test. " $\mathrm{P}<0.05$. Oxo-M, oxotremorine; CHO-M1, human muscarinic type 1 receptor; KCNQ1, potassium voltage-gated channel subfamily Q member 1; F, fluorescence; Fmin, minimum fluorescence; Fmax, maximum fluorescence; Fo, baseline fluorescence; WT, wild-type.

reported that obesity along with IS may modify methylation of $K C N Q 1$ gene and plasma $K C N Q 1$ protein concentration $(38,39)$. The coding variants in KCNQ1 have been reported to lead to congenital long QT syndrome (42), an autosomal dominant disorder. Because of the demonstrated deleterious properties of the investigated variants, it should be also considered that the stroke patients in the study may have suffered from an ischemic stroke secondary to a congenital disorder. Whether KCNQ1 variants are disease-associated with ischemic stroke (possibly via platelet function) or disease-causing for congenital QT syndrome (with reportedly higher incidence of ischemic stroke is one of the questions which should be clarified in the future investigations (41).

Moreover, in one of the largest to date GWAS on platelet function, $K C N Q 1$ locus was discovered to contribute to platelet function variability $(19,20)$. The exact mechanism of these interactions remains unknown, as $K C N Q 1$ is mostly co-assembled with the product of the KCNE1 (minimal 
$\mathrm{K}^{+}$-channel protein) gene in the heart to form a cardiac-delayed rectifier-like $\mathrm{K}^{+}$current and the effect of KCNQ1 channels on platelet function has not been not directly investigated so far. However, Gallego-Fabrega et al (43) reported recently that the methylation pattern of KCNQ1 locus might be associated with vascular recurrence in aspirin-treated stroke patients.

The study is limited by the absence of independent verification of accumulation of deleterious KCNQ1 rare variants. However, it was demonstrated previously that the occurrence of rare variants, because of their private character, is often limited to very restricted cohorts and has been difficult to repeat in other cohorts, unless the confirmation cohorts are truly large (in this case several tens of thousands of patients). The added drawback of the presented research is that the direct effect of the observed genomic variants on the platelet function (e.g. aggregation) was not evaluated. This might raise an issue if the observed change in the frequency of variants were entirely related to the platelet function or, perhaps, some other mechanisms related to biochemical pathways. Moreover, it should be noted that only a limited number of all known genes related to platelet function were re-sequenced in this study. We would like to stress that the results of re-sequencing of the more frequently investigated 26 genes related to platelet function were published by our group in the past (13).

The outcome of this study indicates that the increased accumulation of rare damaging variants in the exons of the sequenced 54 platelet genes (and in particular for variants located in the region of potassium channel KCNQ1 gene) could be associated with LVIS. The mechanism of the interaction of these variants with LVIS currently appears unclear and therefore requires further investigations. It is also uncertain if our results could be directly translated to other populations, as the variants responsible for the observed associations appear to be limited to the investigated cohort. Further studies in different, as well as much larger cohorts, are required to address this problem.

\section{Acknowledgements}

The authors would like to thank Dr Michal Karlinski (Institute of Psychiatry and Neurology, Warsaw, Poland) and Dr Agnieszka Cudna (Center for Preclinical Research and Technology CEPT, Warsaw, Poland) for preparing the samples and database for further analysis.

\section{Funding}

Research subject was implemented with CEPT infrastructure financed by the European Union-the European Regional Development Fund within the Operational Program 'Innovative economy' for 2007-2013. The study was supported financially as part of the research grant from the National Science Center OPUS research grant (grant no. 2013/11/B/NZ7/01541).

\section{Availability of data and materials}

The datasets used and/or analyzed during the current study are available from the corresponding author on reasonable request.

\section{Authors' contributions}

PKJ and MP conceived the concept and design for the study, were involved in data collection and analysis, and supervised the work. CE and VRV contributed to the design of the research, and were involved in data collection and analysis. SS and YIK verified the analytical methods. JP, AC, IKJ and DMG were involved in data collection and analysis. All authors read and approved the final manuscript.

\section{Ethics approval and consent to participate}

All procedures followed were in accordance with the ethical standards of the responsible committee on human experimentation (institutional and national) and with the Helsinki Declaration of 1975, as revised in 2000. Informed consent was obtained from all patients for being included in the study.

\section{Patient consent for publication}

The consent for publication was obtained from all patients included in the study.

\section{Competing interests}

The authors declare that they have no competing interests.

\section{References}

1. Welter D, MacArthur J, Morales J, Burdett T, Hall P, Junkins H, Klemm A, Flicek P, Manolio T, Hindorff L and Parkinson H: The NHGRI GWAS Catalog, a curated resource of SNP-trait associations. Nucleic Acids Res 42: D1001-D1006, 2014.

2. Holliday EG, Maguire JM, Evans TJ, Koblar SA, Jannes J, Sturm JW, Hankey GJ, Baker R, Golledge J, Parsons MW, et al: Common variants at $6 \mathrm{p} 21.1$ are associated with large artery atherosclerotic stroke. Nat Genet 44: 1147-1151, 2012.

3. Bevan S, Traylor M, Adib-Samii P, Malik R, Paul NL, Jackson C, Farrall M, Rothwell PM, Sudlow C, Dichgans M and Markus HS: Genetic heritability of ischemic stroke and the contribution of previously reported candidate gene and genomewide associations. Stroke 43: 3161-3167, 2012.

4. Gibson G: Rare and common variants: Twenty arguments. Nat Rev Genet 13: 135-145, 2011.

5. Genome of the Netherlands Consortium: Whole-genome sequence variation, population structure and demographic history of the Dutch population. Nat Genet 46: 818-25, 2014.

6. Cheng YC, Cole JW, Kittner SJ and Mitchell BD: Genetics of ischemic stroke in young adults. Circ Cardiovasc Genet 7: 383-392, 2014.

7. Auer PL, Nalls M, Meschia JF, Worrall BB, Longstreth WT Jr, Seshadri S, Kooperberg C, Burger KM, Carlson CS, Carty CL, et al: Rare and coding region genetic variants associated with risk of ischemic stroke: The NHLBI exome sequence project. JAMA Neurol 72: 781-788, 2015.

8. Lindgren A: Stroke genetics: A review and update. J Stroke 16: 114-123, 2014.

9. Anyanwu C, Hahn M, Nath M, Li J, Barone FC, Rosenbaum DM and Zhou L: Platelets pleiotropic roles in ischemic stroke. Austin J Cerebrovasc Dis Stroke 3: 1048, 2016.

10. del Zoppo GJ: The role of platelets in ischemic stroke. Neurology 51 (Suppl 3): S9-S14, 1998.

11. Milanowski L, Pordzik J, Janicki PK and Postula M: Common genetic variants in platelet surface receptors and its association with ischemic stroke. Pharmacogenomics 17: 953-971, 2016.

12. Postula M, Janicki PK, Milanowski L, Pordzik J, Eyileten C, Karlinski M, Wylezol P, Solarska M, Czlonkowka A, Kurkowska-Jastrzebka I, et al: Association of frequent genetic variants in platelet activation pathway genes with large-vessel ischemic stroke in Polish population. Platelets 28: 66-73, 2017. 
13. Janicki PK, Eyileten C, Ruiz-Velasco V, Sedeek KA, Pordzik J, Czlonkowska A, Kurkowska-Jastrzebska I, Sugino S, Imamura-Kawasawa Y, Mirowska-Guzel D and Postula M: Population-specific associations of deleterious rare variants in coding region of P2RY1-P2RY12 purinergic receptor genes in large-vessel ischemic stroke patients. Int J Mol Sci 18: E2678, 2017.

14. Jones CI, Bray S, Garner SF, Stephens J, de Bono B, Angenent WG Bentley D, Burns P, Coffey A, Deloukas P, et al: A functional genomics approach reveals novel quantitative trait loci associated with platelet signaling pathways. Blood 114: 1405-1416, 2009.

15. Goodall AH, Burns P, Salles I, Macaulay IC, Jones CI, Ardissino D, de Bono B, Bray SL, Deckmyn $\mathrm{H}$ and Dudbridge F, et al: Transcription profiling in human platelets reveals LRRFIP1 as a novel protein regulating platelet function. Blood 116: 4646-4656, 2010.

16. Postula M, Janicki PK, Rosiak M,Kaplon-Cieslicka A, Trzepla E, Filipiak KJ, Kosior DA, Czlonkowski A and Opolski G: New single nucleotide polymorphisms associated with differences in platelets reactivity in patients with type 2 diabetes treated with acetylsalicylic acid: Genome-wide association approach and pooled DNA strategy. J Thromb Thrombolysis 36: 65-73, 2013.

17. Guerrero JA, Rivera J, Quiroga T, Martinez-Perez A, Antón AI, Martínez C, Panes O, Vicente V, Mezzano D, Soria JM and Corral J: Novel loci involved in platelet function and platelet count identified by a genome-wide study performed in children. Haematologica 96: 1335-1343, 2011.

18. Mathias RA, Kim Y, Sung H, Yanek LR, Mantese VJ, Hererra-Galeano JE, Ruczinski I, Wilson AF, Faraday N, Becker LC and Becker DM: A combined genome-wide linkage and association approach to find susceptibility loci for platelet function phenotypes in European American and African American families with coronary artery disease. BMC Med Genomics 3: 22, 2010.

19. Johnson AD, Yanek LR, Chen MH, Faraday N, Larson MG, Tofler G, Lin SJ, Kraja AT, Province MA, Yang Q, et al: Genome-wide meta-analyses identifies seven loci associated with platelet aggregation in response to agonists. Nat Genet 42: 608-613, 2010

20. Johnson AD: The genetics of common variation affecting platelet development, function and pharmaceutical targeting. J Thromb Haemost 9 (Suppl 1): S246-S257, 2011.

21. Shiffman D, Rowland CM, Louie JZ, Luke MM, Bare LA, Bolonick JI, Young BA, Catanese JJ, Stiggins CF, Pullinger CR, et al: Gene variants of VAMP8 and HNRPUL1 are associated with early-onset myocardial infarction. Arterioscler Thromb Vasc Biol 26: 1613-1618, 2006.

22. No authors listed: Stroke-1989. Recommendations on stroke prevention, diagnosis, and therapy. Report of the WHO task force on stroke and other cerebrovascular disorders. Stroke 20 : $1407-1431,1989$

23. Foulkes MA, Wolf PA, Price TR, Mohr JP and Hier DB: The stroke data bank: Design, methods, and baseline characteristics. Stroke 19: 547-554, 1988.

24. Grabska K, Gromadzka G and Członkowska A: Infections and ischemic stroke outcome. Neurol Res Int 2011: 691348, 2011

25. Zawistowski M, Gopalahrishnan S, Ding J, Li Y, Grimm S and Zöllner S: Extending rare-variant testing strategies: Analysis of noncoding sequence and imputed genotypes. Am J Hum Genet 87 : 604-617, 2010.

26. Lee S, Abecasis GR, Boehnke M and Lin X: Rare-variant association analysis: Study designs and statistical tests. Am J Hum Genet 95: 5-23, 2014

27. Lynch M, Bost D, Wilson S, Maruki T and Harrison S: Populationgenetic inference from pooled-sequencing data. Genome Biol Evol 6: 1210-1228, 2014.

28. Kircher M, Witten DM, Jain P, O'Roak BJ, Cooper GM and Shendure J: A general framework for estimating the relative pathogenicity of human genetic variants. Nat Genet 46: 310-315, 2014.
29. Visschedijk MC, Alberts R, Mucha S, Deelen P, de Jong DJ, Pierik M, Spekhorst LM, Imhann F, van der Meulen-de Jong AE, van der Woude CJ, et al: Pooled resequencing of 122 ulcerative colitis genes in a large dutch cohort suggests population-specific associations of rare variants in MUC2. PLoS One 11: e0159609, 2016.

30. Liu JZ, van Sommeren S, Huang H, Ng SC, Alberts R, Takahashi A, Ripke S, Lee JC, Jostins L, Shah T, et al: Association analyses identify 38 susceptibility loci for inflammatory bowel disease and highlight shared genetic risk across populations. Nat Genet 47: 979-986, 2015.

31. Hong KW, Shin MS, Ahn YB, Lee HJ and Kim HD: Genomewide association study on chronic periodontitis in Korean population: Results from the Yangpyeong health cohort. J Clin Periodontol 42: 703-710, 2015.

32. Prescott NJ, Lehne B, Stone K, Lee JC, Taylor K, Knight J, Papouli E, Mirza MM, Simpson MA, Spain SL, et al: Pooled sequencing of 531 genes in inflammatory bowel disease identifies an associated rare variant in BTNL2 and implicates other immune related genes. PLoS Genet 11: e1004955, 2015.

33. McCloskey C, Jones S, Amisten S, Snowden RT, Kaczmarek LK, Erlinge D, Goodall AH, Forsythe ID and Mahaut-Smith MP: $\mathrm{Kv} 1.3$ is the exclusive voltage-gated $\mathrm{K}^{+}$channel of platelets and megakaryocytes: Roles in membrane potential, $\mathrm{Ca}^{2+}$ signalling and platelet count. J Physiol 588: 1399-1406, 2010.

34. Shankar H, Kahner BN, Prabhakar J, Lakhani P, Kim S and Kunapuli SP: G-protein-gated inwardly rectifying potassium channels regulate ADP-induced cPLA2 activity in platelets through Src family kinases. Blood 108: 3027-3034, 2006.

35. Kapural L and Fein A: Suppression of the voltage-gated $\mathrm{K}^{+}$ current of human megakaryocytes by thrombin and prostacyclin. Biochim Biophys Acta 1355: 331-342, 1997.

36. Schmidt EM, Münzer P, Borst O, Kraemer BF, Schmid E, Urban B, Lindemann S, Ruth P, Gawaz M and Lang F: Ion channels in the regulation of platelet migration. Biochem Biophys Res Commun 415: 54-60, 2011.

37. Al-Shammari MS, Al-Ali R, Al-Balawi N, Al-Enazi MS, Al-Muraikhi AA, Busaleh FN, Al-Sahwan AS, Al-Elq A, Al-Nafaie AN, Borgio JF, et al: Type 2 diabetes associated variants of KCNQ1 strongly confer the risk of cardiovascular disease among the Saudi Arabian population. Genet Mol Biol 40: 586-590, 2017.

38. Gómez-Úriz AM, Milagro FI, Mansego ML, Cordero P, Abete I, De Arce A, Goyenechea E, Blázquez V, Martínez-Zabaleta M, Martínez JA, et al: Obesity and ischemic stroke modulate the methylation levels of KCNQ1 in white blood cells. Hum Mol Genet 24: 1432-1440, 2015.

39. Abete I, Gómez-Úriz AM, Mansego ML, De Arce A, Goyenechea E, Blázquez V, Martínez-Zabaleta MT, González-Muniesa P, López De Munain A, et al: Epigenetic changes in the methylation patterns of KCNQ1 and WT1 after a weight loss intervention program in obese stroke patients. Curr Neurovasc Res 12: 321-333, 2015.

40. Harmer SC, Mohal JS, Royal AA, McKenna WJ, Lambiase PD and Tinker A: Cellular mechanisms underlying the increased disease severity seen for patients with long QT syndrome caused by compound mutations in KCNQ1. Biochem J 462: 133-142, 2014.

41. Liu J, Wang F, Wu Y, Huang X, Sheng L, Xu J, Zha B, Ding H, Chen $Z$ and Sun T: Meta-analysis of the effect of KCNQ1 gene polymorphism on the risk of type 2 diabetes. Mol Biol Rep 40: 3557-3567, 2013.

42. Henninger N, Haussen DC, Kakouros N, Selim M, Searls DE, Kumar S, Schlaug G and Caplan LR: QTc-prolongation in posterior circulation stroke. Neurocrit Care 19: 167-175, 2013.

43. Gallego-Fabrega C,Carrera C, Reny JL,FontanaP,Slowik A,Pera J, Pezzini A, Serrano-Heras G, Segura T, Bin Dukhyil AA, et al: PPM1A methylation is associated with vascular recurrence in aspirin-treated patients. Stroke 47: 1926-1929, 2016. 